\title{
THE LACK OF PROFIT-AND-LOSS SHARING FINANCING IN INDONESIA'S ISLAMIC BANKS: REVISITED
}

\author{
A s c a ry a \\ Center of Education and Central Banking Studies \\ Bank Indonesia \\ Jakarta, Indonesia \\ Email: ascarya@bi.go.id
}

\begin{abstract}
The lack of profit and loss sharing (PLS) financing is a global phenomenon affecting Islamic banks worldwide. This paper analyzes problems faced by Indonesia's Islamic banks using the Analytic Network Process (ANP) methodology. The preliminary step is to decompose the problem through questionnaires and in-depth interviews with scholars and practitioners of Islamic banking to fully comprehend the envisaged problem and develop an appropriate ANP network. The next step is to evaluate and measure the model using pair-wise comparisons and then to synthesize in order to find solutions. The root of the problem can be grouped into two aspects, namely Islamic bank internalities, which include upper management, human resources and technical aspects, and externalities that include society, the authorities and customers. The results show that Internal problems have shifted from human resources (lack of quality and quantity; risk averse) to technical aspects (IT and SOP) as well as upper management (commitment), while external problems have expanded slightly from the Government (lack of supportive regulations; incentives) to the Government (lack of commitment; lack of support) and society (lack of trust; lack of perception). The policies to be instituted by regulators have broadened to include not only directed market-driven policy, but also professionalism. Moreover, the operational strategies for market development that should be implemented include service improvement programs as well as socialization and communication programs to address the most acute internal and external weaknesses of Islamic banking and finance in Indonesia.
\end{abstract}

Keywords: ANP, Islamic Banking, Profit-and-Loss Sharing

\section{Introduction}

\subsection{Background}

Since the establishment of Bank Muamalat Indonesia in 1992, Islamic banking began to develop in Indonesia. Gradually, Islamic banks have served the public who require financial or banking services that in line with the teaching of Islam, especially the prohibition of riba, speculation or gambling, uncertainty, unfairness in transactions, and the obligation to invest in and finance ethical and halal businesses according to Shariah Law.

The development of Islamic banking became more significant after the government and Bank Indonesia (the Central Bank of Indonesia) committed to expand Islamic banking more vigorously through supporting policies, in particular since the amendment of Banking Regulation no. 10. 1998. Various policies not only related to office expansion and operation to improve the supply side, but also to the amelioration of public understanding and consciousness of Islamic banking to improve the demand side. When conventional banks were permitted to open Islamic branches the growth of Islamic banks mushroomed.

In 2000 , there were two Islamic banks and three Islamic branches with only 65 offices and a $0.17 \%$ share of total assets. Notwithstanding, at the end of 2008 there were five Islamic banks and 27 Islamic 
branches with a total of 953 offices and 1470 counters of office channeling in conventional banks. The share of total assets has reached $2.14 \%$ or Rp.49.55 trillion with $36 \%$ growth.

The expansive growth of Islamic banking in Indonesia is also evidenced by deposits collected and financing extended. In 2000, deposits totaled Rp.1.03 trillion and financing extended amounted to Rp.1.27 trillion, with a 123.3\% FDR (financing to deposit ratio). At the end of 2008, deposits grew by $32 \%$ annually reaching Rp.36.85 trillions, while financing grew by $37 \%$ per year and reached Rp.38.2 trillions, with a $103.6 \%$ FDR. Such a strong FDR represents a significant achievement compared to Islamic banks in other countries, and it was far beyond the LDR (loan to deposit ratio) of conventional banks in Indonesia, which achieved 77.7\%.

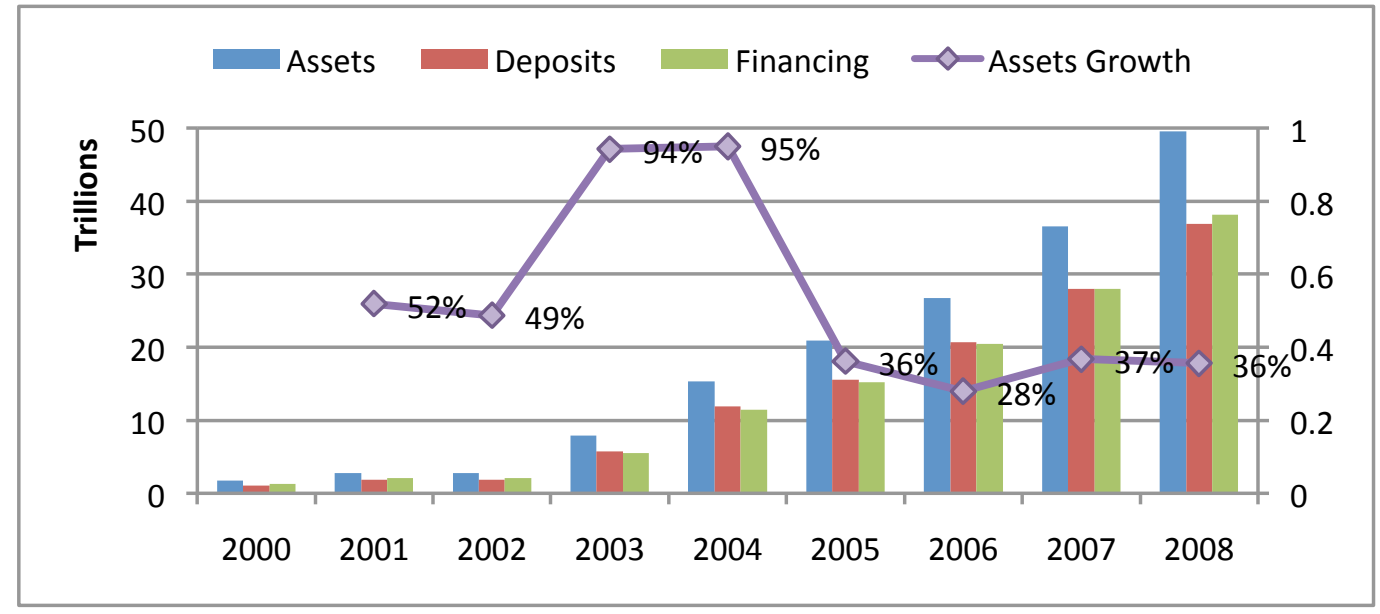

Figure 1.1 Growth of Islamic Banking in Indonesia

Nevertheless, by the end of 2008, the financing portfolio comprised of $19.4 \%$ musyarakah, $16.3 \%$ mudharabah, 58.9\% murabahah, and 5.5\% other modes of financing (see Figure 1.2). The portfolio was dominated by non profit-and-loss (PLS) financing (64.4\%), particularly murabahah. Meanwhile, the share of PLS financing (mudharabah and musyarakah) was only $35.7 \%$, even though PLS financing is not only the essence of Islamic financing but also a more appropriate mode of financing to catalize the real sector, stabilize the financial system and curb inflation, since it can improve direct interaction and risk sharing between investors and entrepreneurs.

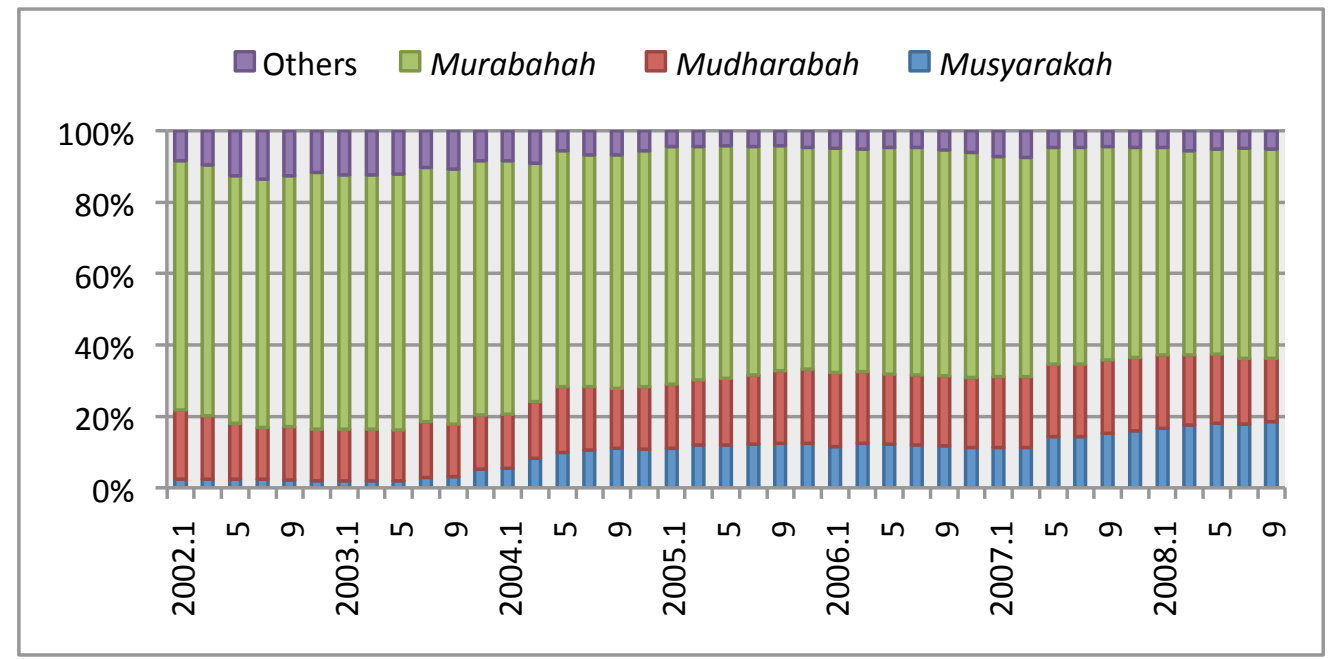

Figure 1.2 Financing Portfolio of Islamic Banks

Most ulamas and scholars also agreed that Islamic banks share the main principle of PLS. Therefore, PLS financing must be placed at the forefront and dominate non-PLS financing. Nevertheless, a 
number of other scholars have opined that the tendency to opt for non-PLS financing was normal in the early stages of an Islamic bank's development because of the various initial constraints faced.

Above and beyond this debate, the phenomenon of low PLS financing is an important subject to discuss. Various problems and their alternative solutions must be identified in order to expand the share of PLS financing. Moreover, low PLS financing tends to be a multi-dimensional problem that has existed for a long time, and there is no sign of improvement. The domination of non-PLS financing encourages the public to perceive Islamic banking as almost identical to conventional banking. This perception could spur reputation risk for Islamic banks, sparking cynicism in public sphere that Islamic banking is just a re-branding, while the mind-set of the bankers remains conventional. The problem of low PLS financing becomes even more significant when we see it happening in other countries that have Islamic banks, especially in countries with a dual banking system, such as Egypt, Bangladesh, Pakistan, and Malaysia.

Low PLS financing is clearly not the expected ideal. The Islamic banking industry, the Government, and Bank of Indonesia must continue to improve the system and its supporting infrastructure as well as find appropriate solutions to promote PLS financing.

The old adage that Rome was not built in a day seems incredibly apt in this context. Therefore, to improve PLS financing we must begin as early as possible, because ongoing industry development requires direction to ensure it moves forward on the right track.

\subsection{Objectives}

The objectives of this study are to identify factors that influence low PLS financing in Indonesia's Islamic banking industry and find alternative solutions and policy strategies to counter it. Moreover, the results of this study can be used as input and feedback by related stakeholders, such as the Islamic banking industry, investors, entrepreneurs, Bank Indonesia and the Government to take appropriate policy actions in order to overcome the current problems and accomplish the expected goals.

\subsection{Methodology}

This study applies ANP methodology in three steps. First, questionnaires and in-depth interviews with scholars, experts, practitioners, customers and regulators of Islamic banking are conducted to fully comprehend the real problems and identify factors affecting low PLS financing. Second, the results of the preliminary stage are used to develop an appropriate ANP network and relevant questionnaires to glean the necessary data from experts and practitioners of Islamic banking. Third, ANP analysis is applied to set priority alternative solutions and policy strategies in order to formulate optimal policy recommendations.

\section{Literature Review}

Islamic banking has been around for more than 30 years. However, Islamic banking remains widely unknown in the western world of finance and has only recently been introduced in a few western countries, such as UK, Germany and Singapore. Therefore, this section briefly introduces Islamic banking.

\subsection{Introduction to Islamic Banking}

An Islamic bank is a financial institution that operates to expedite economic activities in the real sector through business activities (such as investment, trade, etc.) which comply with Shariah Law pursuant to the teachings of Islam between a bank and its customers in funding and/or financing business activities or other activities in accordance with macro and micro Islamic values. Macro values include justice and fairness (' $a d l$ ), beneficial to society (maslahah), zakah system, free of usury or interest (riba), free of speculative and unproductive activities (maysir), free of unclear terms and conditions (gharar), and free of defective and unlawful transactions (bathil). The micro values that 
have to be embedded in Islamic bank practitioners include the admirable attributes exemplified by the Prophet Muhammad s.a.w., namely, truthful (shiddiq), reaching out (tabligh), trustworthy (amanah) as well as competent and professional (fathonah). Moreover, the success dimensions of Islamic banks include success in this world (short-term oriented) and in the hereafter (long-term oriented), which concern purity of the source, correctness of the process and utility of the outcome.

Funding activities of Islamic banks can be carried out through investment deposits (mudharabah or PLS investment accounts), investment savings (mudharabah or PLS saving accounts), deposit savings (wadiah saving accounts), and deposit checking (wadiah checking accounts). The funds accumulated then invested in the business community through the respective bank's own investment (trade financing) and collaborative investment with the third party (investment financing). When the bank earns a profit, this profit is shared with its funding partners (depositors). Islamic banks can also provide financial services to their customers (see Figure 2.1).

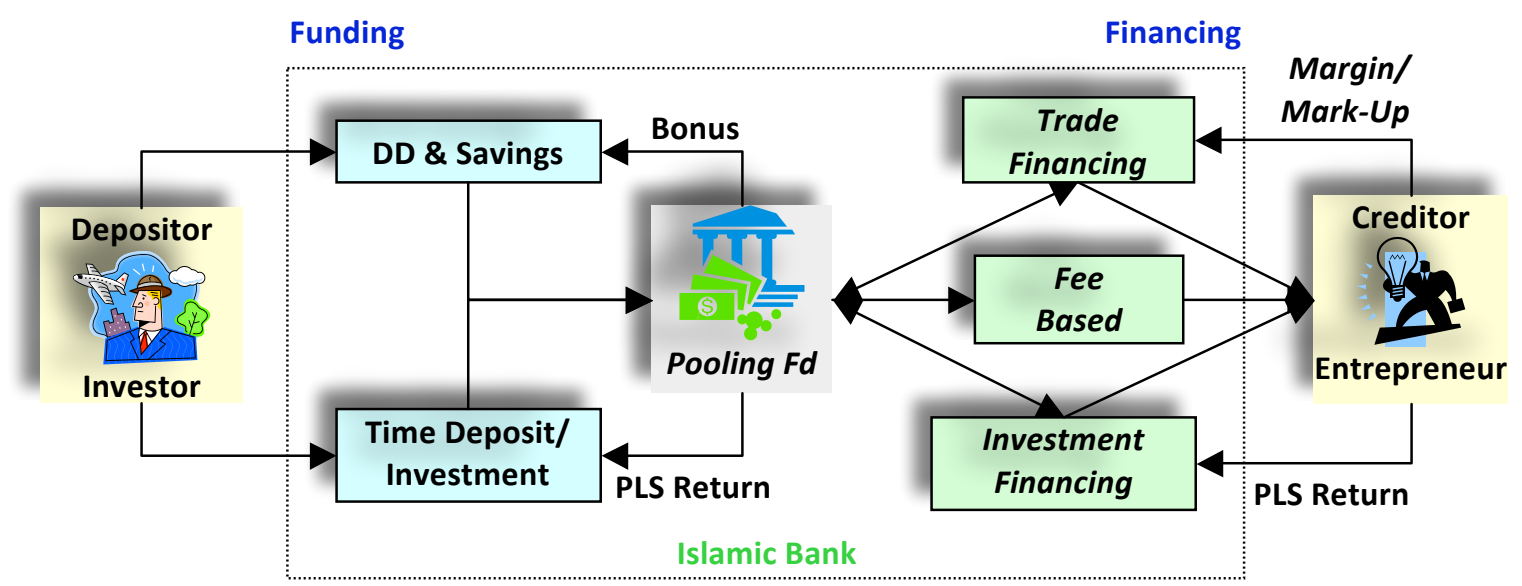

Figure 2.1 Operation of Islamic Bank

\subsection{Previous Studies}

The lack of PLS financing or the domination of non-PLS financing, especially murabahah, in the portfolio of Islamic banking financing is a global phenomenon, not only occurring in Indonesia but worldwide. Furthermore, it is not only found in new Islamic banks (still in the transitional stage) but also in established Islamic banks. Nevertheless, according to Chapra (2000) steps for improvement are within sight. For example, information from the International Association of Islamic Banks (IAIB) showed that the proportion of murabahah, which reached $90 \%$ of total financing, declined to $40.3 \%$ in 1996. Meanwhile, mudharabah and musyarakah financing increased to $7.2 \%$ and $12.7 \%$, respectively. Nevertheless, PLS is still marginal with a share of below $20 \%$ of total financing. The problem of low PLS financing is a multi dimensional issue. Several experts had tried to identify the root of the problem, which seems impossible to decompose.

This revisited study is based on a previous study (Ascarya and Yumanita, 2005; 2006) conducted in 2004. The problem was grouped into four aspects, namely Islamic bank internalities, customers, regulations, and the Government. The clusters were grouped into problems, alternative solutions, and development strategies. The details are as follows.

a. Internal

1) Lack of understanding of Islamic banking fundamentals;

2) Emphasis on business or profit orientation (business-oriented);

3) Lack of quality and quantity of human resources;

4) Islamic banks are still averse to efforts; and

5) Islamic banks are still averse to risks.

b. Customer

6) Lack of understanding of Islamic banking fundamentals; and 
7) Customers are still averse to risks.

\section{c. Regulation}

8) Lack of incentives to stimulate PLS financing; and

9) Lack of supportive regulations.

d. Government

10) Lack of government commitment and support.

\section{e. Alternative Solutions}

1. Improvement of human resources in their knowledge and understanding of Islamic Banking fundamentals (internal);

2. Development of innovative, attractive, and simple products (internal);

3. Socialization of Islamic banking and its products (customer);

4. Supportive regulations and incentive system (regulation); and

5. Harmonization of responsibilities and relationships of DSN, DPS and BI in order to create synergy (government).

\section{f. Development Strategies}

1. Market-driven strategy; a strategy to follow market conditions or demand so that the government or regulator do not institute direct policies or regulations that intervene and disrupt the market. The policies and regulations are intended to stimulate a fair market mechanism;

2. Supply-led strategy; a strategy to direct the market inline with the desired goals using policies and/or regulations; and

3. Directed market-driven strategy; a strategy to follow the market and indirectly coax it towards the desired direction.

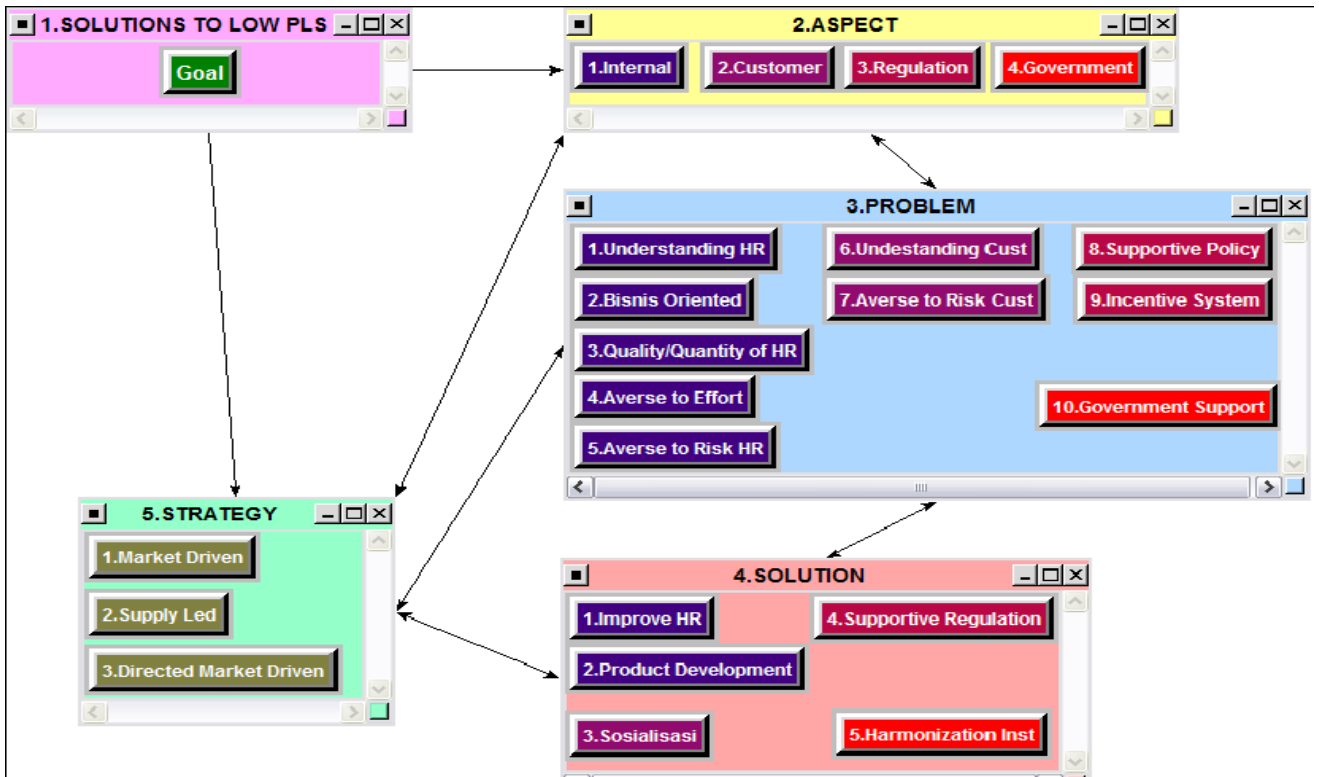

Figure 2.2 ANP Network of Low PLS Financing using Superdecisions

The ANP network is shown in Figure 2.2. Holistically, the results show that the order of priority concurs with the experts' opinions on where the key problems lie concerning internal and regulatory aspects. Lack of human resources in terms of quality and quantity as well as risk aversion are the core problems internally. With respect to regulatory aspect, the lack of supportive policies is a major problem. Therefore, the solutions that should be given priority are to improve human resources regarding their knowledge and understanding of Islamic Banking and promote supportive regulations and an incentive system. Moreover, a suitable policy strategy to effectively resolve the existing problem would be to apply a directed market-driven strategy. 


\section{Current Study}

A lack of PLS financing in Indonesia's Islamic banks remains after five years of development; since the previous study. Therefore, this study revisits the problem taking into consideration the innovative new developments as well as the changes that have occurred over the past five years.

\subsection{Steps of Research}

This study comprises of several steps, namely, 1) questionnaires and in-depth interviews with experts and practitioners to understand the problem comprehensively; 2) decomposition to identify, analyze and structure the complexity of the problem into an appropriate ANP network; 3) form pair-wise questionnaires according to the ANP network; 4) in-depth interviews with experts and practitioners to complete pair-wise questionnaires; 5) synthesis and data processing using ANP software Superdecisions; 6) results analysis and policy recommendations.

In the first step, questionnaires are sent via email to 20 practitioners of Islamic banking from various Islamic banks and 15 Islamic finance experts from various institutions, universities and consulting firms. Follow-up is conducted through in-depth interviews to garner more detailed information. The most knowledgeable respondents (seven practitioners and seven experts) are chosen to be the respondents of the pair-wise questionnaire. Step two is elaborated over the next two sections, while step five and six are elaborated thereafter.

To simplify the original rather complicated pair-wise questionnaires and to maintain consistency, a new modified pair-wise questionnaire is used as shown in Figure 3.1. Meanwhile, the respondents are equipped with a show card describing the scale and the ANP network.

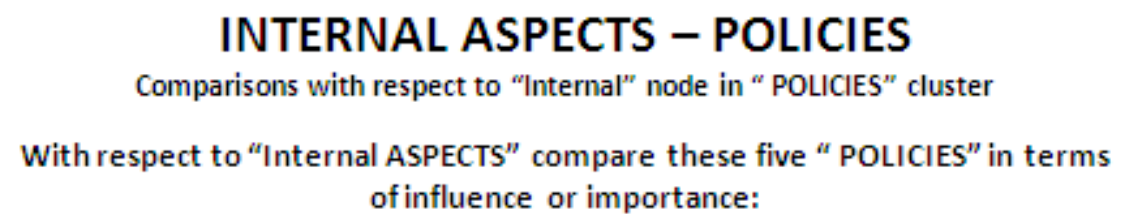

\begin{tabular}{|c|c|c|c|c|c|c|c|c|c|}
\hline \multirow{2}{*}{ ASPECTS } & \multicolumn{9}{|c|}{ SCALE } \\
\hline & 1 & 2 & 3 & 4 & 5 & 6 & 7 & 8 & 9 \\
\hline Directed Marketing Driven & & & $x$ & & & & & & \\
\hline Fair Treatment & $x$ & & & & & & & & \\
\hline Gradual \& Sustainable & & $\mathrm{x}$ & & & & & & & \\
\hline Shariah Compliance & & & & $x$ & & & & & \\
\hline Professionalism & & & & $x$ & & & & & \\
\hline
\end{tabular}

Figure 3.1 Sample of Simplified Pair-wise Questionnaire

The modified pair-wise questionnaire will significantly reduce the time required for interviews with respondents and will provide consistent results. For example, the time taken to complete the entire pair-wise questionnaire of more than 1,200 questions was less than two hours.

\subsection{Problem Identification}

According to the opinions of several experts' opinions ${ }^{1}$, as well as questionnaire and in-depth interviews with local experts and practitioners, contemporary factors causing low PLS financing can still be viewed from internally and externally. Internal aspects include upper management, human

\footnotetext{
${ }^{1}$ Chapra (2000), Iqbal and Llewellyn (2002), Dar and Presley (2000), Sarker (1999), Algaoud and Lewis (2001), Mulyawan (2001), Al-Jarhi (2002) and Parinduri (2003).
} 
resources, and technical, while external aspects include society, the authorities, and customers. The subsequent clusters are grouped into problems, solutions, policies and strategies with the details as follows:

\section{a. Internal Problems}

1. Upper Management (Board of Commissioners and Board of Directors)

- Lack of understanding in Islamic economy, finance and banking fundamentals;

- Emphasis on business or profit orientation (business-oriented);

- Risk averse and risk transfer behavior still leads to the inability to accept the possibility of loss; and

- Lack of commitment to improve the portfolio of PLS financing.

2. Human Resources

- Lack of knowledgeable and skilled human resources with expertise in Islamic banking and Shariah Law;

- Emphasis on business targets or profit (target-oriented);

- Risk averse and risk transfer behavior still lead to inability to accept the possibility of loss; and

- Aversion to diversification efforts because it is more complicated to deal with PLS financing than to deal with other modes of financing.

3. Technical Aspects

- Less applicable than other modes of financing for working capital, small businesses or longterm projects;

- Higher risk than other modes of financing, while Islamic banks are still unable to manage higher risk;

- More complicated to structure and deal with PLS financing than to structure and deal with other modes of financing;

- Islamic banks have insufficient management tools to manage higher risk or to analyze and measure investment risk adhering to Islamic principles.

\section{b. External Problems}

1. Society

- Multi-ethnic and multi-religious affiliations have sensitized society to issues of ethnicity and religiosity (unity through diversity is more important);

- Lack/loss of trust in society has introduced agency problem and asymmetric information that lead to moral hazard and adverse selection;

- Inaccurate perceptions of Islam and riba have made society ignorant to Islamic finance and banking;

- Lack of understanding and knowledge regarding the fundamentals of the Islamic economy, finance and banking;

2. Authority

- Lack of understanding in Islamic economy, finance and banking fundamentals;

- Lack of political commitment, political will, and political courage to support the development of Islamic finance and banking;

- Lack of supporting infrastructure (hard and soft) in the development of Islamic finance and banking;

- Lack of incentives and efforts to promote PLS-based finance.

3. Customer

- Lack of understanding and knowledge concerning the fundamentals of the Islamic economy, finance, and banking;

- Customers (depositors/borrowers) are naturally risk averse because they are not accustomed to the possibility of loss and are accustomed to an interest rate system;

- Low demand for PLS financing due to its limited applicability and unpopularity;

- The majority of Islamic banks' customers are floating (not loyal) customers.

c. Internal Solutions 
1. Upper Management

- Appropriate 'Fit and Proper Test' for BOC or BOD candidates;

- Management commitment to apply PLS financing as the main mode of financing;

- Reward and Punishment mechanism to promote PLS financing.

2. Human Resources

- Introduce a thorough human resource selection process;

- Ameliorate human resources knowledge and skills in Islamic banking and Shariah Law;

- Incentive system for Islamic bank officers extending PLS-based financing.

3. Technical Aspects

- Simplification of standards and procedures in the application of PLS based financing;

- Development of innovative and attractive yet simple PLS-based products;

- Development of Information Technology and Standard Operating Procedures in the extension of PLS financing.

d. External Solutions

1. Society

- Extensive and intensive socialization of IEFB and PLS financing;

- Effective da'wah (outreach to the people) for IEFB and PLS financing;

- Systematic and comprehensive education system from elementary school up to higher education;

2. Government/Authority

- Political commitment, political will and political courage to support the development of IEFB and PLS financing;

- Government support of hard and soft infrastructure in the development of IEFB;

- $\quad$ Supportive regulations to foster IEFB and PLS-based financing.

3. Customer

- Education offered to customers and potential customers regarding PLS financing;

- A systematic and concerted national promotion program to nurture PLS financing;

- An incentive system for customers to choose PLS-based financing.

e. Policies

- A directed market-driven policy gives equal priority to government initiatives and external solutions, as well as market initiatives and internal solutions;

- Fair Treatment;

- Gradual and Sustainable;

- Shariah Compliant; and

- Professionalism.

f. Development Strategies

- $\quad$ New Image Program;

- New Mapping of Market Segmentation;

- Product Development Program;

- Service Improvement Program; and

- Socialization and Communication Program.

\subsection{Conceptual Framework}

Based on identification of problems, the conceptual framework developed in this study is shown in Figure 3.2. 


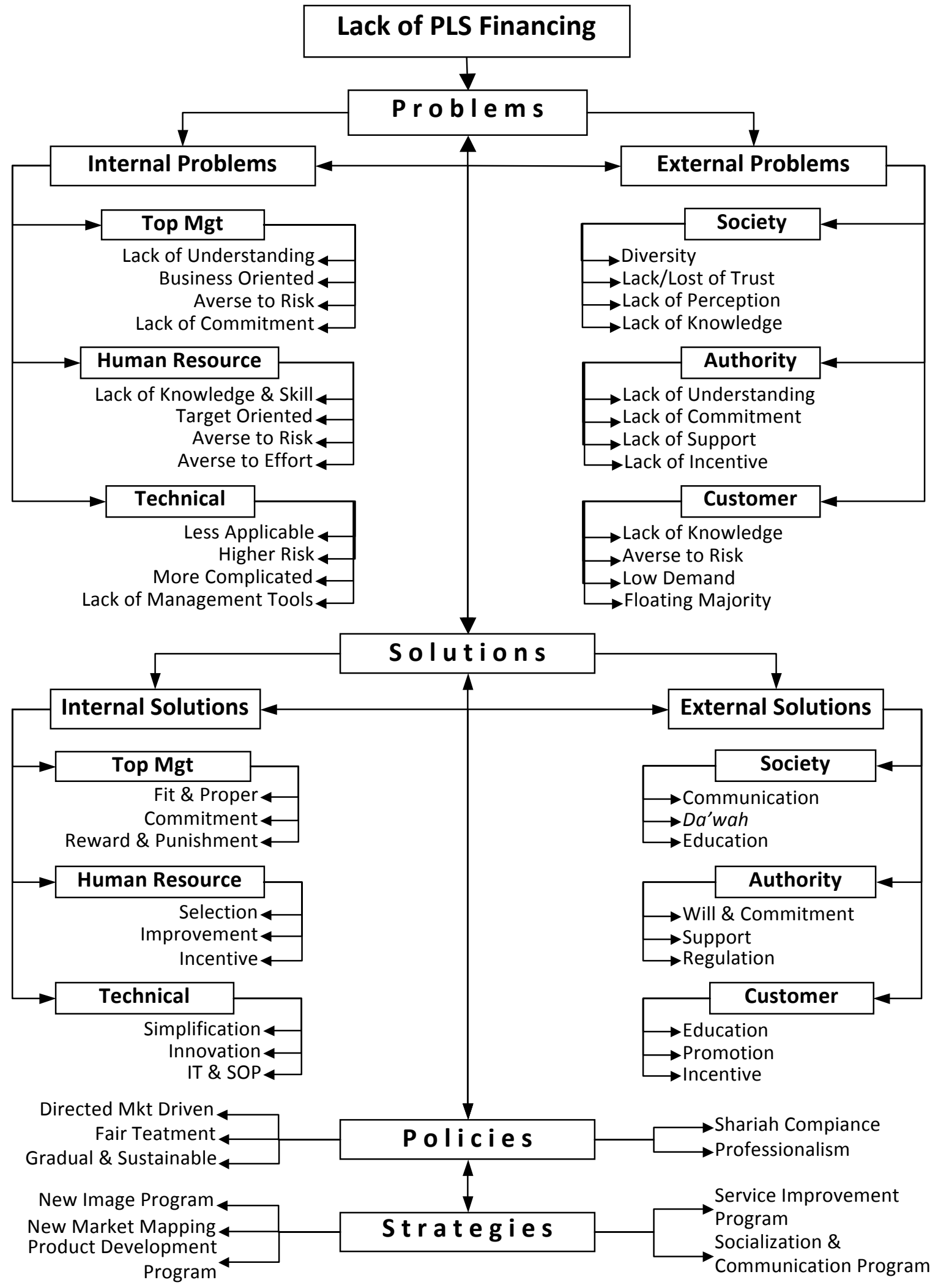

Figure 3.2 Conceptual Framework

Therefore, the ANP network of the above conceptual framework is as follows: 


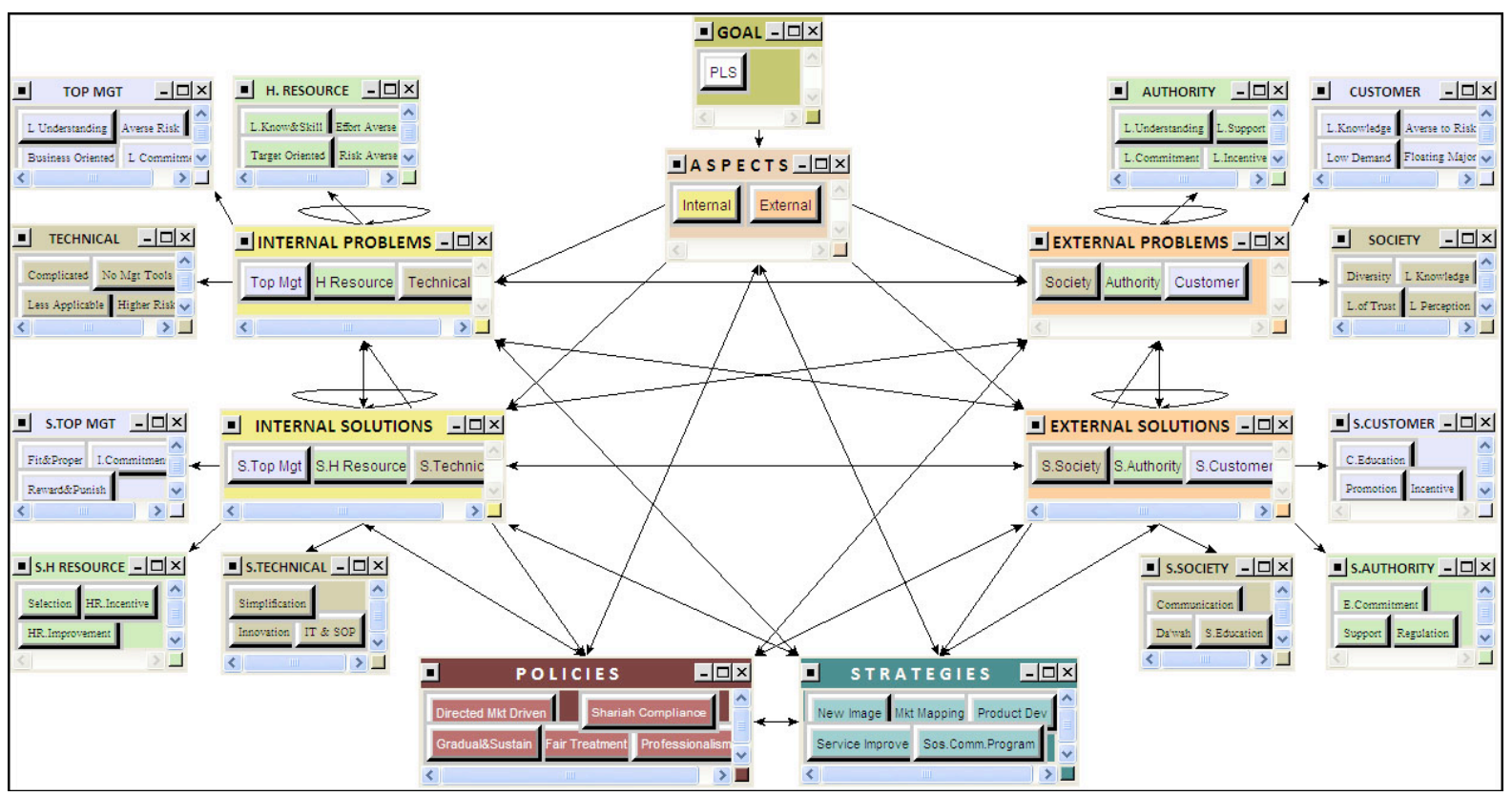

Figure 3.3 New ANP Network of Low PLS Financing

\subsection{Results and Analysis}

Complete results are presented in Appendix 1. The lack of PLS financing can be divided almost evenly into internal (0.496) and external (0.504) problems, specifically into technical aspects $(0.420)$ and authority (0.435). Internal problems have changed slightly from human resources in 2004 to technical aspects in 2009, while the external problems have expanded from merely a lack of supportive regulations in 2004 to authority commitment and support in 2009. These developments show that over the past five years the issues of human resources have lowered in priority due to the additional five years' worth of experience and development. Many public and private universities have established Islamic Economic, Finance and Banking (IEFB) Studies, Departments or Schools. Moreover, numerous IEFB Training Institutions have also been established. Meanwhile, regulations have also become a lower priority due to, among others, the promulgation of the Islamic Banking Act, Sovereign Sukuk (Islamic Bonds) Act, an array of Bank Indonesia regulations and several International Islamic Banking Standards.

\begin{tabular}{|c|c|c|c|c|}
\hline ASPECTS & \multicolumn{2}{|c|}{ PREVIOUS STUDY } & \multicolumn{2}{|c|}{ CURRENT STUDY } \\
\hline & $1^{\text {st }}$ & $2^{\text {nd }}$ & $1^{\text {st }}$ & $2^{\text {nd }}$ \\
\hline $\begin{array}{l}\text { Internal } \\
\text { Problems }\end{array}$ & $\begin{array}{l}\text { Lack of Quality \& } \\
\text { Quantity of Human } \\
\text { Resource }\end{array}$ & Averse to Risk & $\begin{array}{l}\text { Technical: No } \\
\text { Management tools; } \\
\text { Higher Risk }\end{array}$ & $\begin{array}{l}\text { Top Management: Lack } \\
\text { of Commitment; } \\
\text { Business Oriented }\end{array}$ \\
\hline $\begin{array}{l}\text { Internal } \\
\text { Solutions }\end{array}$ & $\begin{array}{l}\text { Human Resource } \\
\text { Improvement }\end{array}$ & & $\begin{array}{l}\text { Technical: IT \& } \\
\text { SOP }\end{array}$ & $\begin{array}{l}\text { Top Management: } \\
\text { Commitment }\end{array}$ \\
\hline $\begin{array}{l}\text { External } \\
\text { Problems }\end{array}$ & $\begin{array}{l}\text { Regulation: Lack of } \\
\text { Supportive } \\
\text { Regulations }\end{array}$ & $\begin{array}{l}\text { Government: } \\
\text { Lack of Support }\end{array}$ & $\begin{array}{l}\text { Authority: Lack of } \\
\text { Commitment; Lack } \\
\text { of Support }\end{array}$ & $\begin{array}{l}\text { Society: Lack of Trust; } \\
\text { Lack of Perception }\end{array}$ \\
\hline $\begin{array}{l}\text { External } \\
\text { Solutions }\end{array}$ & $\begin{array}{l}\text { Supportive } \\
\text { Regulations }\end{array}$ & Incentive & $\begin{array}{l}\text { Authority: } \\
\text { Commitment }\end{array}$ & $\frac{\text { Society: Communication; }}{\text { Da'wah }}$ \\
\hline Policies & $\begin{array}{l}\text { Directed Market } \\
\text { Driven }\end{array}$ & & $\begin{array}{l}\text { Directed Market } \\
\text { Driven }\end{array}$ & Professionalism \\
\hline Strategies & -- & -- & $\begin{array}{l}\text { Service } \\
\text { Improvement }\end{array}$ & $\begin{array}{l}\text { Socialization \& } \\
\text { Communication Program }\end{array}$ \\
\hline
\end{tabular}

Table 3.1 Summary of Results

Internal technical problems undermining an increase in the share of PLS financing arise due to difficulties in developing and standardizing PLS financing schemes for various purposes. Although 
most necessary fatwas and regulations are already in place, Islamic banks still face constraints to make them operational and applicable, due to, among others, lack of regulatory detail and technical problems that make them unable to develop appropriate and simple management tools (0.546) to extend PLS financing. Islamic banks also still perceive PLS financing as higher risk (0.232) compared to other modes of financing and they have not been successful in mitigating the additional risks. Meanwhile, the external authorities have been a problem since the first study in 2004 due to ambivalence regarding the development of IEFB. Consequently, the development of IEFB in Indonesia has remained demand driven, while the relevant authorities have only responded when necessary. This condition has led to a lack of commitment (0.467) and a lack of support (0.277) from the authorities for the development of IEFB, especially in promoting PLS financing. For example, the types of Sovereign Sukuks issued by the Treasury Department are all Ijarah Sukuk (lease-based Sukuk), not Mudharabah or Musharakah Sukuk (PLS-based Sukuk). Moreover, the Islamic monetary instruments implemented by Bank Indonesia are also non-PLS based.

Another internal problem affects upper management (i.e., Board of Commissioners and Board of Directors) due to their lack of commitment (0.467) and their propensity for business matters $(0.277)$. Consequently, the PLS financing is not a business priority. Notwithstanding, external problems are also attributable to society. The most acute problem of society in the implementation of PLS financing is a loss of trust (0.546), which is prerequisite for business partnerships. Another important societal issue is the lack of perception (0.232) with PLS financing perceive as more expensive, less beneficial and riskier than other modes of financing.

The problems have shifted, ergo, the priority solutions have also changed. The top priority solution to resolve the internal technical problems is the development of Information Technology and Standard Operating Procedures (0.637) for Islamic banks to standardize and simplify the process of PLS financing. As a result, all Islamic bank' officials are encouraged and motivated to offer PLS financing to their clients and customers. The top priority solution for problems concerning external authorities is their political will, political commitment and political courage $(0.500)$ to seriously develop IEFB, especially PLS-based finance. The next priority solution to internal upper management problems is their commitment to apply PLS financing as the main mode of financing $(0.540)$, while the solutions to external societal problems are communication (0.400) and $d a$ 'wah (0.400).

The priority 'policies' to be taken by regulators have changed a little, but have expanded. Previously, the top priority policy was directed market-driven policy, while currently top priority policies are directed market-driven (0.218) and professionalism (0.218). Directed market-driven policy has reappeared in the current study as regulators have opted for market-driven policy, but it has not been effective in promoting or expanding the share of PLS financing. Under this policy, Islamic banks are free to choose the modes of financing to use. Therefore, the simplest one is usually opted for, i.e. trade financing (murabahah). As a result, without any authoritarian intervention, it will be difficult to convince Islamic banks to use PLS financing as priority. Moreover, professionalism has become a priority because it is necessary to extend PLS financing eagerly.

Finally, more operational strategy cluster were added to the current study in order to answer some strategic operational problems. Among the five grand strategies of market development, service improvement programs $(0.308)$ as well as socialization and communication programs $(0.236)$ have emerged as the two most important to be implemented. These two programs mitigate the internal and external weaknesses of Islamic banking and IEFB as a whole in Indonesia. Service area has become a major deficiency of most Islamic banks in Indonesia that needs to be seriously addressed immediately. Meanwhile, socialization and communication to the public as well as other potential institutional customers, government officials and other stakeholders are crucial to educate them and attempt to reverse their negative mindset and perceptions toward Islamic banks.

\section{Conclusions and Recommendations}




\subsection{Conclusions}

Based on discussions regarding the lack of PLS financing from Indonesia's Islamic banks presented in this study, a number of important conclusions can be drawn as follows:

1. The lack of PLS financing from Islamic banks has been a persistent global phenomenon since the first establishment of Islamic bank in the 1970s. Although this problem also persists in Indonesia's Islamic banks, the data shows that the use of PLS financing in Indonesia is among the highest compared to that of Islamic banks in other countries. However, this problem should be addressed appropriately because PLS financing provides greater benefits to the economy and society as a whole in terms of reducing inflation, stabilizing the economy, catalyzing real sector growth, reducing unemployment, promoting justice and equality, as well as improving the welfare of society in general.

2. Countries with a dual financial system (where a conventional financial system coexists with an Islamic financial system), such as Pakistan, Malaysia and Indonesia, face a more severe lack of PLS financing than countries with just an Islamic financial system, such as Sudan. Such countries have better and more comprehensive soft and hard infrastructure to extend PLS modes of financing.

3. Compared to conventional banks, Islamic banks in Indonesia are still new with minimal experience. Therefore, the lack of PLS financing should be viewed proportionally by all stakeholders as this is only one of a number of interconnected problems faced by Islamic banks. However, this problem should be given serious attention, especially by the Government and the Islamic banking authority, because it could trigger reputation risk for the 'Shariah' label that is associated with Islamic financial institutions.

4. Compared to the previous study, the lack of PLS financing from Indonesia's Islamic banks has shifted slightly and expanded. Internal problems have moved from human resources related problems (lack of quality and quantity; risk averse) to technical related problems (IT and SOP) and problems with upper management (commitment). External problems have expanded from government related problems (lack of supportive regulations; incentives) to different government related problems (lack of commitment; lack of support) and problems related to society (lack of trust; lack of perception).

5. In line with the shift in issues and the additional problems found, the solutions have also been changed. The solution to internal technical problems is the development of Information Technology and Standard Operating Procedures (0.637) for Islamic banks to standardize and simplify the process of PLS financing. The solution to upper management problems is their commitment to apply PLS financing as the main mode of financing (0.540). Meanwhile, the issues found with the authorities are their political will, political commitment and political courage $(0.500)$ to seriously develop IEFB, especially PLS-based finance. The solution to this is communications (0.400) and da'wah (0.400).

6. The problems relating to the policies instituted by the regulator have expanded to include not only directed market-driven (0.218), but also professionalism (0.218). Directed market-driven policy has reappeared in the current study since the regulator has opted for market-driven policy, but it has not been effective in promoting or expanding the share of PLS financing.

7. The operational strategies for market development that should be adopted are service improvement programs $(0.308)$ as well as socialization and communication programs $(0.236)$ in order to address the most acute internal and external weaknesses of Islamic banking and IEFB as a whole in Indonesia. 


\subsection{Recommendations}

Based on the results of the current study and their relationship with the previous study, some recommendations are suggested as follows:

1. The Government and Islamic Banking Authority should take the lack of PLS financing proportionally but seriously in order to optimize the benefits of PLS-based finance in the nationwide financial system. This implies that PLS-based finance should not only be the principle mode of financing from Islamic banks, but also in the entire Islamic financial system and Islamic monetary system.

2. The Government and Islamic Banking Authority should apply directed market-driven policy to effectively resolve the lack of PLS financing. The market should not be permitted to direct the development of Islamic banks; it is the bank that should also guide the market in the most desirable direction. Furthermore, the regulator should guide the development of IEFB and PLSbased finance. With this policy, the Government and the relevant authorities will be able to implement other priority policies and operational strategies more effectively.

3. To obtain more comprehensive overview of the problem, a further study on the optimal portfolio (PLS and non-PLS financing) of Islamic banks is required that can minimize risks and maximize profits. The study could be used to persuade and guide Islamic banks in the adjustment of their portfolio to a more optimal one.

\section{REFERENCES}

Algaoud, L.M. and Lewis, M.K. (2001). Perbankan Syariah. [translation], Jakarta, Indonesia: Serambi.

Al-Jarhi, M.A. (2002). Islamic Finance: An Efficient and Equitable Option. mimeo, Jeddah, Saudi Arabia: The Islamic Research and Training Institute (IRTI).

Ascarya and Yumanita, D. (2005). Mencari Solusi Rendahnya Pembiayaan Bagi Hasil di Perbankan Syariah Indonesia. Buletin Ekonomi Moneter dan Perbankan, Bank Indonesia, 8(1).

Ascarya and Yumanita, D. (2006). The Lack of Profit and Lost Sharing Financing in Indonesian Islamic Banks: Problems and Alternative Solutions. Paper, INCEIF Islamic Banking and Finance Educational Colloquium, KL Convention Center, Kuala Lumpur, Malaysia, April 3-5.

Dar, H.A. and Presley, J.R. (2000). Lack of Profit Loss Sharing in Islamic Banking. International Journal of Islamic Financial Services, 2(2).

Febianto, I. and Kasri, R.A. (2007). Why Do Islamic Banks Tend to Avoid Profit and Loss Sharing Arrangement?," Paper Proceedings, The 2nd Islamic Conference 2007 (iECONS2007), Faculty of Economics and Muamalat, Islamic Science University of Malaysia.

Hasan, Z. (2002). Mudaraba as a Mode of Finance in Islamic Banking: Theory, Practice and Problems," MPRA Paper, 2951.

Muljawan, D. and Iljas, N. (2003). Adverse Selection dan Implementasi Norma Islami Dalam Kegiatan Ekonomi. Mimeo.

Parinduri, R.A. (2003). Bank Islam Sebenar-benarnya”, Koran Tempo. July 11.

Saaty, T.L. (2005). Theory and Applications of the Analytic Network Process: Decision Making with Benefits, Opportunities, Costs, and Risks. Pittsburgh, PA: RWS Publications. 
Saaty, T.L. and Özdemir, M. (2005). The Encyclicon; a Dictionary of Applications of Decision Making with Dependence and Feedback based on the Analytic Network Process. Pittsburgh, PA: RWS Publications.

Saaty, T.L. and Vargas, L.G. (2006). Decision Making with the Analytic Network Process: Economic, Political, Social and Technological Applications with Benefits, Opportunities, Costs and Risks., New York, NY: Springer Science+Business Media.

Sarker, M.A.A. (1999). Islamic Business Contracts, Agency Problem and the Theory of the Islamic Firm. International Journal of Islamic Finance Services, 1(2).

APPENDIX 1: RESULTS

\begin{tabular}{|c|c|c|c|c|c|}
\hline Name & Limiting & $\begin{array}{l}\text { Normalized } \\
\text { By Cluster }\end{array}$ & Name & Limiting & $\begin{array}{c}\text { Normalized } \\
\text { By Cluster }\end{array}$ \\
\hline \multicolumn{6}{|c|}{ ASPECTS } \\
\hline Internal & 0.024334 & 0.50376 & External & 0.023971 & 0.49624 \\
\hline \multicolumn{3}{|l|}{ INTERNAL PROBLEMS } & \multicolumn{3}{|c|}{ EXTERNAL PROBLEMS } \\
\hline Top Management & 0.044613 & 0.29971 & Society & 0.043501 & 0.29243 \\
\hline Human Resource & 0.041697 & 0.28012 & Authority & 0.064661 & 0.43468 \\
\hline Technical & 0.062546 & 0.42018 & Customer & 0.040594 & 0.27289 \\
\hline \multicolumn{3}{|c|}{ TOP MANAGEMENT PROBLEMS } & \multicolumn{3}{|c|}{ SOCIETY PROBLEMS } \\
\hline Lack Understanding & 0.001126 & 0.16008 & Diversity & 0.000574 & 0.08371 \\
\hline Business Oriented & 0.001950 & 0.27722 & Lack of Trust & 0.003746 & 0.54630 \\
\hline Averse to Risk & 0.000671 & 0.09539 & Lack of Perception & 0.001593 & 0.23232 \\
\hline Lack Commitment & 0.003287 & 6730 & Lack of Knowledge & 0.000944 & 3767 \\
\hline \multicolumn{3}{|c|}{ HUMAN RESOURCE PROBLEMS } & \multicolumn{3}{|c|}{ AUTHORITY PROBLEMS } \\
\hline Lack of Know\&Skill & 0.003072 & 0.46737 & Lack Understanding & 0.001632 & 0.16008 \\
\hline Target Oriented & 0.001822 & 0.27719 & Lack of Commitment & 0.004764 & 0.46729 \\
\hline Averse to Risk & 0.000627 & 0.09539 & Lack of Support & 0.002826 & 0.27719 \\
\hline Averse to Effort & 0.001052 & 0.16005 & Lack of Incentive & 0.000973 & 0.09544 \\
\hline \multicolumn{3}{|c|}{ TECHNICAL PROBLEMS } & \multicolumn{3}{|c|}{ CUSTOMER PROBLEMS } \\
\hline Less Applicable & 0.000826 & 0.08376 & Lack of Knowledge & 0.002246 & 0.35094 \\
\hline More Complicated & 0.001358 & 0.13771 & Averse to Risk & 0.001210 & 0.18906 \\
\hline Higher Risk & 0.002291 & 0.23233 & Low Demand & 0.000698 & 0.10906 \\
\hline No Mgt. Tools & 0.005386 & 0.54619 & Floating Majority & 0.002246 & 0.35094 \\
\hline \multicolumn{3}{|c|}{ INTERNAL SOLUTIONS } & \multicolumn{3}{|c|}{ EXTERNAL SOLUTIONS } \\
\hline Top Management & 0.045616 & 0.30644 & Society & 0.043266 & 0.29085 \\
\hline Human Resource & 0.041558 & 0.27918 & Authority & 0.063376 & 0.42604 \\
\hline Technical & 0.061682 & 0.41437 & Customer & 0.042115 & 0.28311 \\
\hline \multicolumn{3}{|c|}{ TOP MANAGEMENT SOLUTIONS } & \multicolumn{3}{|c|}{ SOCIETY SOLUTIONS } \\
\hline Fit \& Proper & 0.002136 & 0.29700 & Communication & 0.002728 & 0.40000 \\
\hline Commitment & 0.003881 & 0.53963 & Da'wah & 0.002728 & 0.40000 \\
\hline Reward \& Punishment & 0.001175 & 0.16338 & Education & 0.001364 & 0.20000 \\
\hline \multicolumn{3}{|c|}{ HUMAN RESOURCE SOLUTIONS } & \multicolumn{3}{|c|}{ AUTHORITY SOLUTIONS } \\
\hline Selection & 0.001562 & 0.23844 & Commitment & 0.004996 & 0.50000 \\
\hline Improvement & 0.000894 & 0.13647 & Support & 0.002498 & 0.25000 \\
\hline Incentive & 0.004095 & 0.62510 & Regulation & 0.002498 & 0.25000 \\
\hline \multicolumn{3}{|c|}{ TECHNICAL SOLUTIONS } & \multicolumn{3}{|c|}{ CUSTOMER SOLUTIONS } \\
\hline
\end{tabular}




\begin{tabular}{|l|l|l|l|l|l|}
\hline Simplification & 0.002512 & 0.25833 & Education & 0.003794 & $\mathbf{0 . 5 7 1 4 7}$ \\
\hline Innovation & 0.001018 & 0.10469 & Promotion & 0.000948 & 0.14279 \\
\hline IT \& SOP & 0.006194 & $\mathbf{0 . 6 3 6 9 8}$ & Incentive & 0.001897 & 0.28574 \\
\hline \multicolumn{5}{|l|}{} & \multicolumn{1}{l|}{ STRATEGIES } \\
\hline POLICIES & 0.028662 & $\mathbf{0 . 2 1 8 2 7}$ & Market Mapping & 0.012748 & 0.09708 \\
\hline Directed Mkt Driven & 0.027456 & 0.20908 & New Image Program & 0.022444 & 0.17091 \\
\hline Fair Treatment & 0.018526 & 0.14108 & Product Development & 0.024625 & 0.18752 \\
\hline Gradual \& Sustainable & 0.027944 & 0.21280 & Service Improvement & 0.040445 & $\mathbf{0 . 3 0 8 0 0}$ \\
\hline Shariah Compliance & 0.028728 & $\mathbf{0 . 2 1 8 7 7}$ & Sos\&Comm Program & 0.031055 & $\mathbf{0 . 2 3 6 4 9}$ \\
\hline Professionalism & \multicolumn{5}{l}{} \\
\hline
\end{tabular}

